\title{
BUT RUTH CLUNG TO HER \\ TEXTUAL CONSTRAINTS ON AMBIGUITY IN RUTH 1:14
}

Scott N. Callaham

\begin{abstract}
Summary
Researchers commonly assert that deliberately ambiguous language in Ruth 3 kindles sexual tension in the depiction of Ruth's nocturnal encounter with Boaz upon his threshing floor. Perhaps inspired by the literary artistry of the author of Ruth, some recent interpreters have also averred that an erotic undercurrent flows through words they deem intertextually suggestive and allusively ambiguous in Ruth 1:14 as the text reads, 'but Ruth clung to her'. The present study critically examines this proposal in light of interrelated semantic, syntactic, and intertextual literary evidence.
\end{abstract}

\section{Semantics of דבק}

Although the lyrical nature of Ruth 1:16-17 dramatically underscores דבק the depth of devotion Ruth expresses toward Naomi, it is the verb ('cling') in verse 14 that constitutes the primary point of departure for proposals of a sexually-charged motivation behind Ruth's actions. ${ }^{1}$ Even when a given commentator does not advocate a lesbian subtext to דבק Ruth 1:14, highlighting alleged erotic connotations lying behind is commonplace in critical literature. ${ }^{2}$ Focus upon the meaning of key

1 Mona West, 'Ruth' in The Queer Bible Commentary, ed. Deryn Guest, Robert E. Goss, Mona West, and Thomas Bohache (London: SCM, 2006): 190-94, esp. 191; Theodore W. Jennings, Jr, Jacob's Wound: Homoerotic Narrative in the Literature of Ancient Israel (New York: Continuum, 2005): 228; J. Cheryl Exum, Plotted, Shot, and Painted: Cultural Representations of Biblical Women (JSOTSup 215; Gender, Culture, Theory 3; Sheffield: Sheffield Academic Press, 1996): 134.

2 Kristin Moen Saxegaard, Character Complexity in the Book of Ruth (FAT II/47; Tübingen: Mohr Siebeck, 2010): 117, 129; Alicia Ostriker, 'The Book of Ruth and the Love of the Land', BibInt 10 (2002): 343-59, esp. 354; Irmtraud Fischer, Rut (HTKAT; Herder: Freiberg, 2001): 142; Katharine Doob Sakenfeld, Ruth (Interpretation; 
words is especially relevant to interpretation of the book of Ruth, for its unfolding plot manifests careful word selection through its employment of certain words as leitmotifs. It follows that the use of דבקק rather than some other word in Ruth 1:14 likely carries significance. Therefore delimiting the semantic range of דבק is a reasonable foundational step toward evaluating any 'sexual subtext hypothesis' concerning the Ruth-Naomi relationship.

A relatively common verb, דבק appears four times in Ruth, with fifty more appearances in fifteen other books of the Hebrew Bible. ${ }^{3}$ Detailed rehearsal of the research available in standard lexicons and dictionaries is not necessary in the present study. ${ }^{4}$ However, several salient findings arise from such data and merit emphasis, for they narrow the range of texts available for the assertion of a sexual component in the basic sense of 'clinging' that lexicographic works assign to דבק.

First, uses of דבק that involve personal relationship of subject and oblique complement (the object-like entity within a prepositional phrase) only comprise roughly half of the overall data set. ${ }^{5}$ Second, of the twenty-eight instances in which דבק links subject and oblique complement in personal relationship, two-thirds (19) involve humans exclusively rather than divine-human interaction. Third, of those nineteen texts only four bear plausible reference to interpersonal

Louisville: John Knox, 1999): 30; Ellen van Wolde, Ruth and Naomi (tr. John Bowden; Macon, GA: Smyth \& Helwys, 1998): 21-22; Robert L. Hubbard, The Book of Ruth (NICOT; Grand Rapids: Eerdmans, 1988): 115.

3 Only 203 other verbs out of a vocabulary stock of 1,345 appear more frequently in the Hebrew Bible than דבק. These statistics derive from searches on Bibleworks 8 with Westminster Hebrew Morphology 4.10 (2008) and exclude the single Biblical Aramaic employment of its cognate verb דבק in Dan. 2:43.

4 Ludwig Koehler and Walter Baumgartner, The Hebrew and Aramaic Lexicon of the Old Testament, s.v. 'דבק' (Boston: Brill, 2001); Ernst Jenni, 'דבקd dbq to hang on' in Theological Lexicon of the Old Testament, ed. Ernst Jenni and Claus Westermann (3 vols.; tr. Mark E. Biddle; Peabody, MA: Hendrickson, 1997): 1:324-25; George J. Brooke, 'דבק' in New International Dictionary of Old Testament Theology and Exegesis, ed. Willem A. VanGemeren (5 vols.; Grand Rapids: Zondervan, 1997): 1:910-12; David J. A. Clines, ed., Dictionary of Classical Hebrew, s.v. 'דבקי' (Sheffield: Sheffield Academic Press, 1993-); Gerhard Wallis, 'דָ G. Johannes Botterweck et al., eds., Theological Dictionary of the Old Testament (15 vols.; tr. John T. Willis (Grand Rapids: Eerdmans, 1974-): 3:79-84.

5 Impersonal use of דב includes the clinging of the tongue to the roof of the mouth (Job 29:10, Ps. 137:6, Lam. 4:4, Ezek. 3:26) or the gums (Ps. 22:16), the clinging of a loincloth to one's loins (Jer. 13:11), and even the grip of disease upon a person (Deut. 28:60, 2 Kgs 5:27), among others. 
relationships with a sexual component. Treatment of each of them appears below.

Gen. 2:24 Therefore a man leaves his father and his mother, he clings to his wife, and they become one flesh. ${ }^{6}$

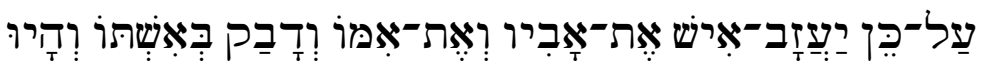

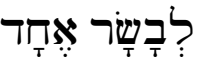

The verb דבק indeed appears in discussion about a sexual relationship - that of husband and wife-in Genesis 2:24. Because of the central, pivotal role that intertextual evidence from Genesis 2:24 plays in assertions of a homosexual relationship between Naomi and Ruth, the present study defers further treatment of Genesis 2:24 to Section 3.3 below.

Josh. 23:12 For if you turn and cling to the remainder of these peoplesthese who are left with you-, and you intermarry with them and come into them and they into you ...

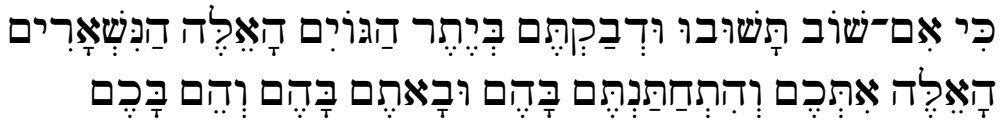

Once again, 'clinging' appears in the context of the husband-wife relationship. Joshua 23:12 refers to sexual activity implicitly through discussion of marriage and explicitly by euphemistic employment of the verb בוץ ('come').

Gen. 34:3 His soul clung to Dinah daughter of Jacob. He loved the girl, and he spoke tenderly to her.
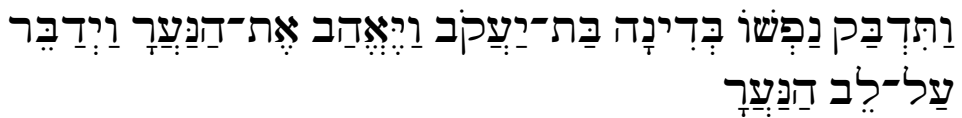

The next text under consideration is Genesis 34:3. Shechem is the actor, and Dinah is the one acted upon. In a sequence of wayyiqtol verbs beginning in the previous verse, Shechem saw, took, lay with, raped, clung to, loved, and spoke to Dinah. Sensitivity to Shechem's scandalous desecration of Dinah is not merely a modern predilection; the enraged response of Dinah's brothers resulted in their slaughter of every male in Shechem's town. At worst, in Genesis 34:3 the act of

6 All Hebrew translations in the present study derive from the author.

7 Stefan Schorch, Euphemismen in der Hebräischen Bibel (Orientalia Biblica et Christiana 12; Wiesbaden: Harrassowitz, 2000): 221. 
'clinging' calls to mind non-consensual, humiliating, violent sex. At best, 'clinging' represents a turn-however slight-away from violating sex acts toward loving abstention from sexual activity, even to the point of agreeing to receive debilitating adult circumcision. In both scenarios, the verb דבק constitutes negation of mutual sexual activity rather than its advocacy.

$1 \mathrm{Kgs}$ 11:2 ... from the peoples of which Yнwн had said to the children of Israel, 'You must not come into them, and they must not come into you. They will surely turn your hearts after their gods.' To them Solomon clung in love.

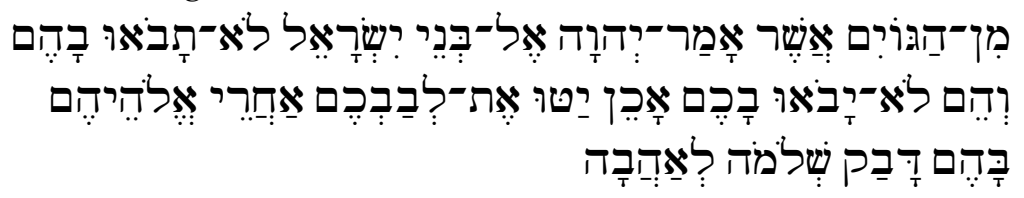

Lastly, 1 Kings 11:2 appears within a catena of complaints about Solomon's faithlessness to YHWH stemming from his embrace of foreign wives. At first glance it appears that 1 Kings 11:2 stands דבק 23:12 as a text in which contributes to description of presumably sexual relationships. While the reader expects Solomon to 'cling' to his many wives in a manner that includes sex, the grammatical gender of the oblique complement of דבק is masculine. Now it is important to note that use of masculine suffixed pronouns for feminine referents is a routine occurrence in the Hebrew Bible. ${ }^{8}$ Verses 3-4 likewise employ masculine gender Hiphil wayyiqtol forms of the verb נטה ('turn aside'), for which the grammatical subjects are Solomon's wives. However, gender agreement patterns in the immediate context are not fully consistent, for verse 8 switches to feminine gender with its Hiphil and Piel participles.

Returning to the masculine oblique complement of דבק in verse 2, it is likely that the text's fluidity of grammatical gender congruence allows for Solomon also to 'cling' to a much closer referent, the

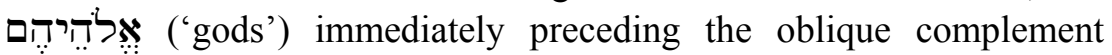
rather than solely the 'many foreign women' of the previous verse.

8 Paul Joüon and Takamitsu Muraoka, A Grammar of Biblical Hebrew (SubBi 27; Rome: Pontifical Biblical Institute, 2006): 516; Bruce K. Waltke and M. O'Connor, $A n$ Introduction to Biblical Hebrew Syntax (Winona Lake, IN: Eisenbrauns, 1990): 302; Emil F. Kautzsch, ed., Gesenius' Hebrew Grammar (tr. Arthur E. Cowley; New York: Clarendon, 1910): 440. 
Indeed, the text decries the offense of Solomon's devotion to foreign gods at length in 1 Kings 11:1-10. If Solomon 'clings' both to his wives and their gods, then sexuality is incidental rather than in the foreground of the text's employment of דבק in verse 2.

Thus far, discussion of the semantics of דבק calls into question the presence of a basic sexual component in its 'clinging' denotation, narrowing the corpus of passages in which a sexual relationship is possible to four verses out of nineteen. Within this small subset, semantic evidence is decidedly equivocal. On one hand, Genesis 2:24 and Joshua 23:12 address personal relationships in which sexuality is an integral component. On the other hand, two other texts concern situations in which 'clinging' results in abstaining from sex (Gen. 34:3) and in which the oblique complement of clinging reasonably includes foreign gods (1 Kgs 11:2), thus denying sexuality a place in the immediate field of activity associated with דבק.

Enlarging the data set under consideration by including texts from Ben Sira ${ }^{9}$ and Qumran ${ }^{10}$ only uncovers additional examples of impersonal and religious uses of דבק along with two fragmentary דבק quotations of Genesis 2:24. in the text following Ruth 1:14 (in 2:8, 21, and 23, referring to Ruth 'clinging' to Boaz's field hands) militate against the notion that consistently implies sexual activity. ${ }^{12}$

If indeed דבק th not among a class of words like carry sexual implications when both subject and oblique complement are human, one is free to draw synonyms and antonyms from all texts

9 Sir. 11:9(B), 11:34, 13:1, 31:10a(B). See Pancratius C. Beentjes, The Book of Ben Sira in Hebrew: A Text Edition of All Extant Hebrew Manuscripts and a Synopsis of All Parallel Hebrew Ben Sira Texts (VTSup 68; New York: Brill, 1997).

10 CD 1:17, 8:4; 1QS 1:5, 2:15; 1QH 5:31; 1QH ${ }^{\mathrm{a}}$ 8:25; 1Q42 1:1; 4Q221 5:6 (cf. 1QS 1:5); 4Q255 1:6 (cf. CD 1:17); 4Q280 1:2; 4Q369 f1:11; 4QpsEzek ${ }^{\mathrm{a}}$ 4:10; 4Q392 f1:3; 4Q410 1:4; 4Q416 f2iv:1 (cf. Gen. 2:24); 4Q418 f10ab:4 (cf. Gen. 2:24); 4Q429 f3:4 (cf. 1QH 5:31); 4Q437 f2i:16, f4:2; 4Q438 f3:1, f4ii:2; 4QHymPr 47:1; 4QDibHam ${ }^{a}$ 1.3:11; 4Q521 2.2:9; 4Q524 f4:0; 11QT 54:15 (cf. Deut. 13:5); 11QT 55:10 (cf. Deut. 13:18). See the Qumran Sectarian Manuscripts database by Martin G. Abegg, Jr, 2001. 11 The Biblical Aramaic verb דבק in Dan. 2:43 appears in the context of discussing interethnic sexual relations, but tellingly, together with a negative particle it signifies that these sexual relationships lack the quality of 'clinging' and thus do not endure.

12 Contra Danna Nolan Fewell and David Miller Gunn, Compromising Redemption: Relating Characters in the Book of Ruth (Literary Currents in Biblical Interpretation; Louisville: Westminster/John Knox, 1990): 84. See also Jack M. Sasson, Ruth: A New Translation with a Philological Commentary and a Formalist-Folklorist Interpretation (Baltimore: The Johns Hopkins University Press, 1979): 27-28, 224; Fischer, Rut, 191; Ostriker, 'The Book of Ruth', 354. 
employing דבק in order to determine its semantic field. Among possible synonyms the verb אהבי, 'love', in many passages, and לכד, 'cling together', in Job 41:9, apply particularly to the present study. Outside of Ruth 1:14, one finds the antonyms עזז, 'leave', in Genesis 2:24; עלה, 'go up' (contextually, 'leave'), in 2 Samuel 20:2; and סור, 'depart from', in 1 Kings 3:3 and 18:6.'

\section{Syntax of Ruth 1:14}

As demonstrated above, the balance of semantic evidence weighs heavily against ascribing sexual undertones to דבק, even when both subject and oblique complement are human. Further facilitating evaluation of the 'sexual subtext hypothesis' is the syntax of Ruth 1:14.

Ruth 1:14 Then they lifted their voices and wept again. Orpah kissed her mother-in-law, but Ruth clung to her.

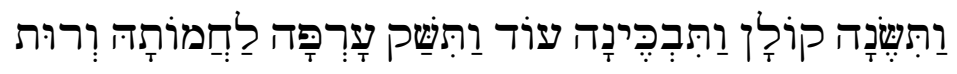

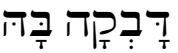

Especially relevant to the present study are the second and third clauses of Ruth 1:14. Some interpreters detect chiastic or 'poetic' word order in these clauses, for 'Orpah kissed her mother-in-law' manifests verbsubject order (AB), and 'but Ruth clung to her', subject-verb (B'A'). ${ }^{14}$ However, such an observation fails to take into account the presence of oblique complements in both clauses, which render their clause constituent orders $\mathrm{ABC}$ and $\mathrm{B}^{\prime} \mathrm{A}^{\prime} \mathrm{C}^{\prime}$. More fruitful syntactical analysis results from recognition that 'Orpah kissed her mother-in-law' is a wayyiqtol verbal clause leading a waw $+x+$ qatal clause, 'but Ruth clung to her'.

Biblical Hebrew narrative carries the main line of its sequence of events through chains of wayyiqtol verbal clauses. Departure from wayyiqtol employment enacts a pause for commentary on the reported

13 Ellen van Wolde, Reframing Biblical Studies: When Language and Text Meet Culture, Cognition, and Context (Winona Lake, IN: Eisenbrauns, 2009): 303 n. 47; Hubbard, The Book of Ruth, 115. Passages with include Gen. 34:3; Deut. 11:22, 30:20; Josh. 22:5; 1 Kgs 11:2; Prov. 18:24.

14 See for example Paul Joüon, Ruth: Commentaire philologique et exégétique (2nd edn; SubBi 9; Rome: Pontifical Biblical Institute, 1986): 41; Edward F. Campbell, Jr, Ruth: A New Translation with Introduction, Notes, and Commentary (AB 7; Garden City, NY: Doubleday, 1975): 14; Jacob Martin Myers, The Linguistic and Literary Form of the Book of Ruth (Leiden: Brill, 1955): 48. 
events. Specifically, in Ruth 1:14 the waw $+x+$ qatal comments by presenting an action (Ruth's act of clinging) that is concurrent with the previous narrative wayyiqtol (Orpah's kiss). ${ }^{15}$ Clarification that this is a 'goodbye kiss' appears in the following verses as Naomi points out that Orpah has 'returned' to her people (v. 15) and Ruth refuses to 'leave' (v. 16). Since 'leaving' is one of the logical opposites of דבק, the function of the waw $+x+$ qatal verbal clause is comment by contrast. ${ }^{16}$ In other words: Orpah leaves, but significantly - at that key moment-Ruth stays. Furthermore, Ruth not only stays with Naomi, she 'clings' to her. Immediately the use of narrative wayyiqtol verbs resumes in Ruth 1:15.

As shown above, the wayyiqtol / waw $+x+$ qatal verbal clause sequence depicts concurrent actions; there is no durative connotation to דבק in Ruth 1:14. Evidence drawn from other biblical passages employing an identical verbal clause sequence and proper noun subjects coheres with this finding. ${ }^{17}$ Even when considered in isolation from the waw $+x+$ qatal construction, the qatal verb conjugation rarely communicates modality, ${ }^{18}$ sharply diminishing the possibility that the syntax of Ruth 1:14 allows atemporal commentary upon the relationship between Ruth and Naomi.

15 Robert D. Holmstedt, Ruth: A Handbook on the Hebrew Text (Baylor Handbook on the Hebrew Bible; Waco, TX: Baylor University Press, 2010): 86-87; Alviero Niccacci, 'Syntactic Analysis of Ruth', Liber Annuus 45 (1995): 69-106, esp. 76; Alviero Niccacci, The Syntax of the Verb in Classical Hebrew Prose (JSOTSup 86; Sheffield: Sheffield Academic Press, 1990; tr. by W. G. E. Watson): 30, 188; Robert Dale Bergen, 'Varieties and Functions of Hebrew Waw-plus-Subject-plus-Perfect Sentence Constructions in the Narrative Framework of the Pentateuch' (Ph.D. dissertation, Southwestern Baptist Theological Seminary, 1986): 195-96.

16 Yair Zakovitch, Das Buch Rut: Ein jüdischer Kommentar mit einem Geleitwort von Erich Zenger, ed. Helmut Merklein and Erich Zenger (Stuttgarter Bibelstudien 177; Stuttgart: Katholisches Bibelwerk, 1999): 95; Francis I. Andersen, The Sentence in Biblical Hebrew (Janua Linguarum Series Practica 231; The Hague: Mouton, 1974): 180.

17 See Gen. 31:25, 36:4; Exod. 9:23, 10:13; 1 Sam. 13:3, 14:46, 15:34, 23:18, 26:25; $1 \mathrm{Kgs} 18: 42 ; 2 \mathrm{Kgs} 9: 30$, 13:13; 2 Chr. 18:31, Esth. 6:12, 7:6; Ps. 105:23. An exception reporting sequential events appears in $1 \mathrm{Chr}$. 5:37.

18 Christo H. J. van der Merwe, Jackie A. Naudé, and Jan H. Kroeze, A Biblical Hebrew Reference Grammar (Biblical Languages: Hebrew 3; New York: Continuum, 1999): 146; Galia Hatav, The Semantics of Aspect and Modality: Evidence from English and Biblical Hebrew (Studies in Language Companion Series 34; Philadelphia: John Benjamins, 1997): 142; Joüon and Muraoka, A Grammar of Biblical Hebrew, 333; Waltke and O'Connor, An Introduction to Biblical Hebrew Syntax, 493; Kautzsch, Gesenius' Hebrew Grammar, 309-313. 


\section{Intertextuality and Ruth 1:14}

\subsection{Levels of Intertexts}

As mentioned previously, the book of Ruth manifests artful word selection that ties its scenes together in a cohesive dramatic whole. Self-evidently, the semantics of דבק and the syntax of Ruth 1:14 aid interpretation of the verse itself and contribute to effective reading of Ruth 1:14 within the overall plot structure of the book of Ruth. Ruth is a self-consciously 'inner-textual' work.

Literary features of the book of Ruth intertextually link the book with other works of the Hebrew Bible: features such as plot motifs, literary style, and vocabulary. Aside from Genesis 2:24, other possible intertexts addressed in critical literature include Genesis 11:27-25:10 (the life of Abraham), ${ }^{19}$ Genesis 13:11-19:38 (the story of Lot after separation from Abraham),${ }^{20}$ the lives of the matriarchs, ${ }^{21}$ Genesis 37, 39-50 (the account of Joseph), ${ }^{22}$ Genesis 38 (the account of Tamar), ${ }^{23}$ Deuteronomy 22-25 (legal material), ${ }^{24} 1$ Samuel 25 (David's acquisition of Abigail as a wife), ${ }^{25} 2$ Samuel 11 (David's acquisition of Bathsheba as a wife), ${ }^{26}$ and 2 Samuel 15:19-22 (David's interactions with Ittai the Gittite). ${ }^{27}$ This list of specific intertext proposals is by no means exhaustive.

19 Phyllis Trible, God and the Rhetoric of Sexuality (OBT 2; Philadelphia: Fortress, 1978): 166-99.

20 Harold Fisch, 'Ruth and the Structure of Covenant History', VT 32 (1982): 425-37; André LaCocque, Ruth: A Continental Commentary (tr. K. C. Hanson; Minneapolis: Fortress, 2004): 30.

21 Alan T. Levenson, 'The Mantle of the Matriarchs: Ruth 4:11-15', JBQ 38 (2010): 237-43.

22 Campbell, Ruth, 5.

23 Mona West, 'Ruth: A Retelling of Genesis 38?' (Ph.D. dissertation, The Southern Baptist Theological Seminary, 1987); Hillel I. Millgram, Four Biblical Heroines and the Case for Female Authorship: An Analysis of the Women of Ruth, Esther, and Genesis 38 (Jefferson, NC: McFarland \& Co, 2008): 77, 87.

24 Michael D. Goulder, 'Ruth: A Homily on Deuteronomy 22-25?' in Of Prophets' Visions and the Wisdom of Sages: Essays in Honor of R. Norman Whybray on His Seventieth Birthday, ed. Heather A. McKay and David J. A. Clines (JSOTSup 162; Sheffield: Sheffield Academic Press, 1993): 307-319.

25 Yitzhak Berger, 'Ruth and Inner-Biblical Allusion: The Case of 1 Samuel 25', JBL 128 (2009): 253-72.

26 Yitzhak Berger, 'Ruth and the David-Bathsheba Story: Allusions and Contrasts', JSOT 33 (2009): 433-52.

27 Victor H. Matthews, 'The Determination of Social Identity in the Story of Ruth', BTB 36 (2006): 49-54, esp. 51. 
Regarding more general biblical themes, an ancient reader of the narrative would likely have viewed Ruth against the backdrop of problematic interethnic relations with Moab through Israelite history. Additionally, controversy over marriages with foreign women could not have been far from the reader's consciousness during the postexilic era. ${ }^{28}$ Indeed, Ruth the foreigner marries into the people of Israel twice and even becomes David's great-grandmother.

Canonical positioning may further stimulate the perception of intertextual connections. ${ }^{29}$ Ruth in the Hebrew canon follows the final

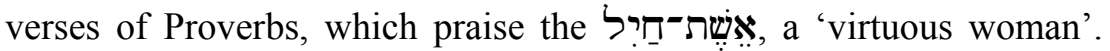
Boaz-himself a 'virtuous man' according to Ruth 2:1 — confers this appellation upon her in Ruth 3:11. In the Septuagintal and Christian canon, Judges immediately precedes Ruth. Moab is an enemy in Judges, and the final chapters of Judges disclose shameful treatment of women and the moral anarchy of people from Bethlehem. ${ }^{30}$ The opening line of Ruth anchors its story to that setting. Then the rest of the book reverses and redeems these negative aspects of Israelite history, at least in the lives of the characters it depicts.

Liturgical use of the book of Ruth prompts additional intertextual thinking among its readership. For example, the traditional Jewish reading of Ruth during Shavuot links the book to mentions of the festival in the Hebrew Bible. ${ }^{31}$ For Christians using the Revised Common Lectionary, selections from Ruth provide alternate Old Testament readings for two consecutive Sundays once per three-year cycle, ${ }^{32}$ drawing these passages into association with New Testament texts.

The categories of intertextuality mentioned above associate the story of Ruth with other texts at multiple levels. Closest to the text is the

28 See Ezra 9-10, Neh. 13:23-39.

29 Kirsten Nielsen, 'Intertextuality and the Hebrew Bible' in Congress Volume: Oslo 1998, ed. André Lemaire and Magne Sæbø (VTSup 80; Boston: Brill, 2000): 17-31, esp. 22; David Jobling, 'Ruth Finds a Home: Canon, Politics, Method' in The New Literary Criticism and the Hebrew Bible, ed. J. Cheryl Exum and David J. A. Clines (Sheffield: JSOT Press, 1993): 125-39.

30 Eugene H. Merrill, 'The Book of Ruth: Narration and Shared Themes', BibSac 142 (1985): 130-41, esp. 131-32.

31 See for example Exod. 34:22; Lev. 23:15-22, esp. 22; Num. 28:26-31; Deut. 26:912 , esp. 11.

32 Consultation on Common Texts, The Revised Common Lectionary (Nashville: Abingdon, 1992). Ruth 1:1-18 resides among the texts for Year B, Proper 26, and Ruth 3:1-5, 4:13-17 is one of the suggested readings for Year B, Proper 27. 
observation of literary correspondences. At slightly greater distance stand broader thematic comparisons. Further still are issues of canonical placement, for they concern the book of Ruth as a whole. Lastly one may consider the historical and contemporary appropriation of Ruth by its readers, a stage of intertextual thinking far removed from the story of Ruth as it appears in the Hebrew Bible.

Though consideration of each level of intertextuality promotes appreciation of the allusive depth of Ruth, as one journeys farther and farther in an outbound quest for intertexts, the voice of Ruth must finally weaken in volume and diminish in clarity to the degree that one loses contact with its resonances and contours altogether. For example, in the case of contemporary readers' use of the Revised Common Lectionary, the proposed intertexts for Ruth reside in the gospel of Mark. Neither Jesus' discussion of the greatest commandment in Mark 12:28-34 nor his castigation of scribes and contrasting praise of a poor widow in Mark 12:38-44 bear connection greater than any other New Testament text to the book of Ruth. ${ }^{33}$ Placement of passages from Ruth in the lectionary alongside these particular gospel readings simply appears arbitrary.

\subsection{Reader-Centric Intertextuality}

The present study thus raises the central, vexed question of intertextuality studies: What justifies the selection of one text as an intertext for another, such as Genesis 2:24 for Ruth 1:14? One prominent stance associated with postmodern literary theory locates the authority for determination of intertext choices at the degree of greatest distance from the text as mentioned above: within the ideology and imagination of the reader. ${ }^{34}$

Such reader-centric intertextuality accounts for the varied reception that texts experience across cultures and subcultures. The more artful the literature at hand, the greater variance one expects in a text's reception. An apt illustration concerns the drama of Ruth 3, which Western imagination inflames with sexual tension under the influence

33 The sole explicit connection of the New Testament text to the book of Ruth appears in Matt. 1:5, which enumerates Ruth, Boaz, and Obed among the ancestors of Jesus.

34 Timothy K. Beal, 'Ideology and Intertextuality: Surplus of Meaning and Controlling the Means of Production' in Reading Between Texts: Intertextuality and the Hebrew Bible (Louisville: Westminster/John Knox, 1992): 27-39, esp. 28. 
of manifold cultural 'intertexts' that demand such a reading. ${ }^{35}$ Yet the mores and expectations of other cultures may require a completely nonsexual reading with equal insistence. ${ }^{36}$

Advocates of reader-centric intertextuality theory express comfort with multivalent, even contradictory readings such as in the case of Ruth 3. Among the essentially unbounded array of possible readings inspired by proposed intertexts will be those that venture beyond the scope of author intention, since "without a reader a text is only a lifeless collection of words'. ${ }^{37}$ Indeed, 'critics at times understand texts better than their creators can'.38 Defining traits of postmodern interpretation include diversity in method and content, as well as rejection of the possibility of widespread agreement on text interpretation. Promoting dialogue, a recent treatise suggests that interpreters 'acknowledge their perspectives, interests, and ideologies' in their work. ${ }^{39}$

While programmatic statements of postmodern interpretive theories emphasise radical openness to varying perspectives, in practice, interpretive claims grounded in such theories resist dialogue with differing points of view. In fact, the reader identity politics at the centre of reader-centric intertextual theory demands scrupulous avoidance of critical engagement, for reader identity politics supplants ideas as the common currency of scholarship. In contrast, critical scholarship requires an open and level field for the interplay of ideas, as well as the conferral of value judgements based upon the perceived merits of arguments drawn from data accessible to all researchers. Furthermore, critical deliberations normally result in the elevation of one perspective over another, an outcome fundamentally at odds with postmodern assumptions. In reality, postmodern theory typically only

35 Van Wolde critiques the vagueness of the postmodern concept of culture as intertext in Ellen van Wolde, 'Texts in Dialogue with Texts: Intertextuality in the Ruth and Tamar Narratives', BibInt 5 (1997): 1-28, esp. 3.

36 Schadrac Keita and Janet W. Dyk, 'The Scene at the Threshing Floor: Suggestive Readings and Intercultural Considerations on Ruth 3', BT 57 (2006): 17-32.

37 Ellen van Wolde, 'Trendy Intertextuality?' in Intertextuality in Biblical Writings: Essays in Honor of Bas van Iersel (Kampen, The Netherlands: Uitgeversmaatschappij J. H. Kok, 1989): 43-49, esp. 47.

38 John Barton, Reading the Old Testament: Method for Biblical Study (Philadelphia: Westminster, 1984): 150-51.

39 George Aichele, Peter Miscall, and Richard Walsh, 'An Elephant in the Room: Historical-Critical and Post-modern Interpretations of the Bible', JBL 128 (2009): 383404, esp. 386. 
accommodates perspectives that cohere with its deconstructionist worldview.

Despite granting a necessary concession to text-centric intertextuality by the act of proposing Genesis 2:24 as an intertext to Ruth 1:14, some postmodern interpreters of Ruth express intentional disengagement from critical concerns in works that employ 'misreading' or 'misprision', ${ }^{40}$ reading 'against the grain', ${ }^{41}$ and even 'parodying' ${ }^{42}$ of the biblical text in order to assert a sexual relationship between Ruth and Naomi. Similarly unsympathetic to the interpretive directions signalled by the biblical text are works that fill narrative gaps with material derived solely from the individual author's imagination. ${ }^{43}$ Narrative gap-filling driven by the imagination lacks controls to screen out anachronistic and idiosyncratic concerns of interpreters, ${ }^{44}$ plays upon ambiguities present in the text, and in its outworking can even result in an interpreter's own use of ambiguous language. Examples of deliberately ambiguous language are references to Ruth and Naomi's 'same-sex love'45 and 'committed'46 relationship as a 'couple'. ${ }^{47}$

40 Lesleigh Cushing Stahlberg, 'Modern Day Moabites: The Bible and the Debate about Same-Sex Marriage', BibInt 16 (2008): 442-75, esp. 442.

41 J. Cheryl Exum, Fragmented Women: Feminist (Sub)versions of Biblical Narratives (Valley Forge, PA: Trinity, 1993): 11.

42 Laurel Bollinger, 'Models for Female Loyalty: The Biblical Ruth in Jeanette Winterson's Oranges Are Not the Only Fruit', Tulsa Studies in Women's Literature 13 (1994): 363-80, esp. 376.

43 Rebecca Alpert, 'Finding Our Past: A Lesbian Interpretation of the Book of Ruth' in Reading Ruth, ed. Judith A. Kates and Gail Twersky Reimer (New York: Ballantine Books, 1994): 91-96, esp. 92. See also Adrien J. Bledstein, 'Female Companionships: If the Book of Ruth were Written by a Woman ...' in A Feminist Companion to Ruth, ed. Athalya Brenner (Sheffield: Sheffield Academic Press, 1993): 116-33, esp. 132; David Rosenberg, A Literary Bible: An Original Translation (Berkeley: Counterpoint, 2009): 142, 553. Bledstein suggests that the reader imagine Tamar, the daughter of David, as the author of Ruth. Rosenberg ventures that Naomi is a fictional persona of the author, a 'Solomonic princess' who is none other than J, the Yahwist.

44 Meir Sternberg, The Poetics of Biblical Narrative: Ideological Narrative and the Drama of Reading (Indiana Literary Biblical Series; Bloomington, IN: Indiana University Press, 1985): 188.

45 Theodore W. Jennings, Jr, The Man Jesus Loved: Homoerotic Narratives from the New Testament (Cleveland: Pilgrim, 2003): 26.

46 Helen Leneman, 'More than the Love of Men: Ruth and Naomi's Story in Music', Interpretation (2010): 146-60, esp. 146.

47 Michael Carden, 'Genesis/Bereshit' in The Queer Bible Commentary, ed. Deryn Guest, Robert E. Goss, Mona West, and Thomas Bohache (London: SCM, 2006): 2160, esp. 34. 


\subsection{Text-Centric Intertextuality and Ruth 1:14}

Critique of reader-centric intertextuality, including exercise of the reader's imagination unchecked by textual warrants and employment of ambiguously suggestive terminology, does not imply that perspectives resulting from the practice of reader-centric intertextuality lack value. On the contrary, the creativity evidenced by this pluriform reading strategy raises questions that demand thoughtful response and can helpfully shape critical dialogue, as long as interpreters agree to dialogue rather than to dismiss work from differing schools of thought outright. Therefore the present study accepts the challenge inherent in reader-centric intertextuality's claim to allow for opposing points of view and argues for respecting the limits that individual texts set upon possible intertextual connections. For while there are indeed no acts of interpretation without interpreters, prior to the act of reading there must also be texts: texts that carry meaning before the first reader sets eyes upon their words. Readers receive their initial signals implying intertextual relationships from within texts. Then citation of literary evidence such as the employment of דבק in Ruth 1:14 commits readers to acceptance of related literary evidence, lest their conclusions result from special pleading.

In an effort to compensate for the great historical and cultural gulf that distances the contemporary reader from the varied settings of the Bible, Richard Hays develops a serviceable means of evaluating intertextual literary evidence and supplies seven criteria that an interpreter may use to detect traces of intertexts in texts under review. ${ }^{48}$ Though Hays's primary texts are the Pauline writings of the New Testament, investigations of intertextual phenomena within the Hebrew Bible itself have profitably employed Hays's criteria or quite similar principles, for example in the study of Isaiah. ${ }^{49}$

\footnotetext{
48 Richard B. Hays, Echoes of Scripture in the Letters of Paul (New Haven: Yale University Press, 1989): 29-31.

49 Jeremy M. Hutton, "Isaiah 51:9-11 and the Rhetorical Appropriation and Subversion of hostile Theologies," JBL 126 (2007): 271-303, esp. 278. Rick Byargeon, 'The Relationship of Micah 4:1-3 and Isaiah 2:2-4: Implications for Understanding the Prophetic Message', SWJT 46/3 (2004): 6-26, esp. 7; Benjamin D. Sommer, A Prophet Reads Scripture: Allusion in Isaiah 40-66 (Stanford: Stanford University Press, 1998): 219-20 n. 12; Patricia Tull Willey, Remember the Former Things: The Recollection of Previous Texts in Second Isaiah (SBLDS 161; Atlanta: Scholars Press, 1997): 81-83. See the proposal of a similar approach in Van Wolde, 'Texts in Dialogue with Texts', $7-8$.
} 
Hays's first criterion concerns availability. A text-centric approach to intertextuality requires the determination that a proposed intertext would have been available in some sense to a biblical author for reflection during the writing process. Since verbal parallels stimulate intertextual investigation, the availability of a written text is most often in view, though the oral transmission of tradition may also account for intertextual influence. ${ }^{50}$ Though the date of authorship of the book of Ruth is a contested issue, it is likely that Genesis 2:24 was available to the author.

The second criterion is volume. Concentration of explicit verbal parallels contributes most significantly to the perception of the volume with which the voices of intertexts resonate in a certain text. In the case דבק 1:14 and Genesis 2:24 reproduced below, the key word supplies the connection.

Ruth 1:14 Then they lifted their voices and wept again. Orpah kissed her mother-in-law, but Ruth clung to her.

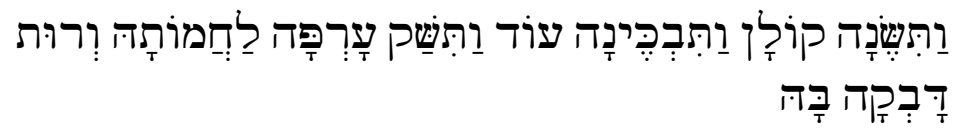

Gen. 2:24 Therefore a man leaves his father and his mother, he clings to his wife, and they become one flesh.

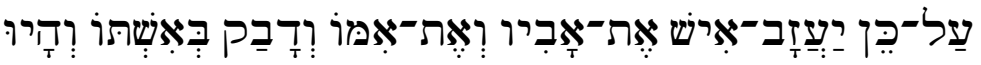

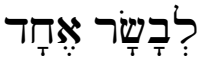

While the 'volume' of a single word sounds weakly as a potential intertextual connection marker, both the Ruth and Genesis verses stand in relief from their own contexts. Genesis 2:24 pauses a narrative chain of wayyiqtols and issues a parenthetical, etiological statement that derives a cultural understanding of husband and wife uniting as 'one flesh' from the story of the LORD God creating Eve from Adam's flesh in Genesis 2:23.

Hays's third criterion is recurrence. In the short book of Ruth there are actually two incidences of verbal parallels to Genesis 2:24. In addition to Ruth 1:14, the text of Ruth 2:11 reports that Boaz says,

50 Westermann argues from a form-critical standpoint that oral transmission of a complex of similar dramatic narratives, of which only Gen. 38 and Ruth survive, accounts for similarities between the Tamar and Ruth stories rather than literary dependence of one of the texts upon the other. See Claus Westermann, 'Structure and Intention in the Book of Ruth', Word \& World 19 (1999): 285-302, esp. 291; Sommer, A Prophet Reads Scripture, 32. 


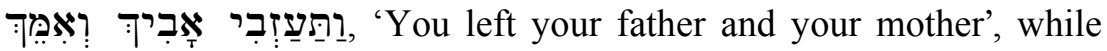

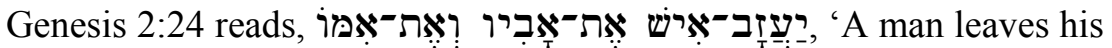
father and his mother'. Though 'father and mother' is a stock phrase appearing thirty-six times in the Hebrew Bible, only Ruth 2:11 and Genesis 2:24 employ it as the object of the verb עזב. ${ }^{51}$

The fourth criterion is thematic coherence, addressing how well Genesis 2:24 serves the development of the plot of Ruth. Departure from Ruth's home-leaving her father and mother-for a new life with Naomi is undoubtedly a significant theme in the book. Likewise, Ruth transfers her primary loyalty to the family she joins by marriage, as the husband does in Genesis 2:24. The final clause of Genesis 2:24 also merits consideration: 'they become becoming 'one flesh' with one's wife is essentially a matter of joining her clan, ${ }^{52}$ then Ruth's commitment to Naomi certainly constitutes a similar decision, and in fact revitalises family ties inaugurated by Ruth's marriage to Naomi's son Mahlon. Yet a thoroughgoing analogy with the context of 'one flesh' in Genesis 2:24 is difficult to sustain. Nothing in the book of Ruth corresponds to the creation of woman from the flesh of man in Genesis 2:23. So whatever the unique phrase בָָָּ probably not among the concepts included in the plausible intertextual references to Genesis 2:24 in Ruth 1:14 and Ruth 2:11.53

Even if one were to entertain faint hints of the 'one flesh' concept transferring from Genesis, contrastingly prominent signals in the immediate literary context point away from reading an incestuous lesbian relationship in line with the themes of the book of Ruth. First, the emotion on display in Ruth's 'clinging' and in her speech in Ruth 1:16-17 is decidedly not an expression of mutual devotion. ${ }^{54} \mathrm{Naomi}$ forcefully and repeatedly pleads for Ruth to leave as the only sensible

51 These findings derive from a search in Bibleworks 8 requiring suffixed pronouns pointing to the same referent. $1 \mathrm{Kgs}$ 19:20 involves a goodbye kiss to Elisha's father and mother, as in Ruth 1:14, and Ps. 27:10 muses upon father and mother abandoning (ע) the psalmist.

52 A. F. L. Beeston, 'One Flesh', VT 36 (1986): 115-17.

53 Childs warns against intertextual 'illegitimate totality transfer' in Brevard S. Childs, 'Critique of Recent Intertextual Canonical Interpretation', ZAW 115 (2003): 173-84, esp. 179.

54 Aviva Zornberg, 'The Concealed Alternative' in Reading Ruth, ed. Judith A. Kates and Gail Twersky Reimer (New York: Ballantine Books, 1994): 65-81, esp. 72; Danna Nolan Fewell and David M. Gunn, “'A Son Is Born to Naomi!”: Literary Allusions and Interpretation in the Book of Ruth', JSOT 40 (1988): 99-108. 
course of action, and Ruth refuses. Naomi's response is silence in Ruth $1: 18$, and she declares to the women of Bethlehem in verse 21 that she left her hometown 'full', but has returned 'empty'. Naomi's anguish is hardly an endorsement of her relationship with her daughter-in-law, whom the text pointedly terms 'Ruth the Moabite' in the following verse..$^{55}$

Hays's fifth criterion addresses historical plausibility: whether the historical context of a literary work's author and initial readership sensibly allows for a reading enriched by a proposed intertextual reference. In the case of the setting of the story of Ruth in the religious literature of the people of Israel, several possible connections to Genesis 2:24 mentioned above fit well among the narrative themes of the Hebrew Bible. However, it is correspondingly difficult to posit a scenario in which the author of Ruth would compose a lesbian romance novella - an otherwise unknown genre in the Ancient Near East - with basic premises running directly counter to Jewish cultural and biblical morality and the overall story line of the book of Ruth itself. Attempts to address the historical problem by postulating that the author outside of the story ${ }^{56}$ or Boaz within $i^{57}$ are unaware of the sexual relationship before their eyes merely deconstruct the historical plausibility criterion and represent disengagement from intertextual evidence present in the text.

The sixth criterion respects the history of interpretation. Hays cautions against employing this criterion over-aggressively in the face of compelling contrary evidence, for it is possible that the passage of centuries has distorted an author's voice in some way. Yet while certain schools of Pauline scholarship may argue that modern interpreters have largely failed to understand Paul as writing from within his original Jewish context and thus have warped his message, in the case of Ruth a review of the history of its interpretation reveals no proposals of a sexual undertone to Ruth 1:14 at any point until the twentieth century.

Hays terms his seventh and final criterion satisfaction. After all other considerations, the intertextually-sensitive reader considers

\footnotetext{
55 D. Dorothea Erbele-Küster, 'Immigration and Gender Issues in the Book of Ruth', Voices from the Third World 25 (2002): 32-39, esp. 34-36.

56 Jeannette H. Foster, Sex Variant Women in Literature (Tallahassee, FL: Naiad, 1985): 29.

57 Jennings, Jacob's Wound, 230.
} 
whether a proposed reading makes sense. Especially regarding the criterion of satisfaction, the subjectivity of the individual reader is on full display. Employment of Hays's seven criteria is much more a matter of art than of science. Even so, if the reader's art focuses upon intertextual data and offers conclusions that are accessible to others, it holds value in a critical context.

\subsection{Review of Intertextuality and Ruth 1:14}

To review, evaluation of Genesis 2:24 as a possible intertext for Ruth 1:14 according to the methodology of Richard Hays generates the following results, listed according to criterion and graded on a strength scale from weak, to unlikely, to neutral, to likely, to strong.

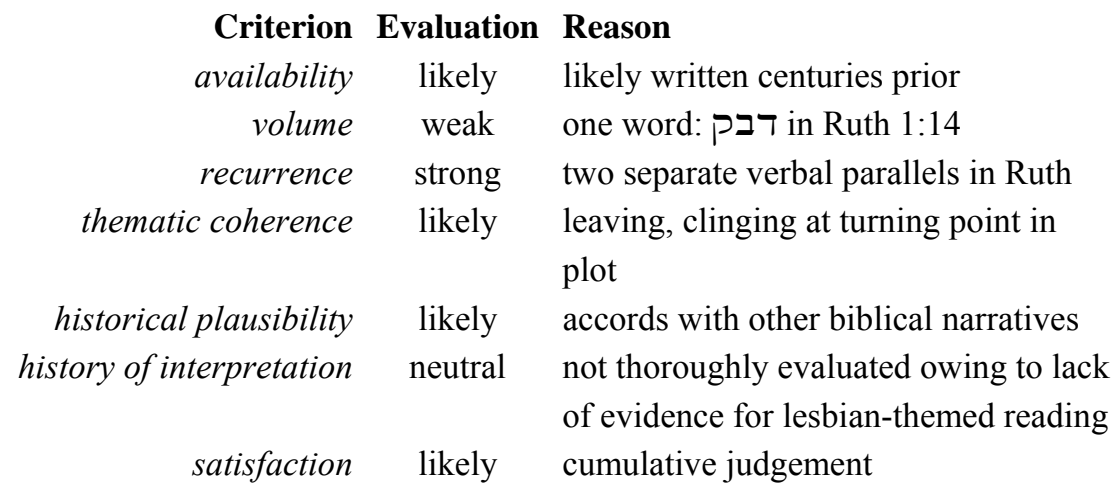

The balance of the Hays criteria leans toward acceptance of Genesis 2:24 as an allusive background text for Ruth 1:14. However, evaluation of the final four criteria turns to 'unlikely' or 'weak' if one requires that the totality of Genesis 2:24 (including a sexually-charged reading of the 'one flesh' clause) transfer as a literary background to Ruth 1:14. A sexual relationship between Ruth and Naomi does not cohere thematically with the plot of the book, is historically implausible, is absent from the history of interpretation until the dawn of postmodernism, and thus presents an unsatisfactory reading from a text-centric intertextual perspective.

\section{Conclusion}

Quality literature provokes the imagination to fill gaps in narrative. Indeed, readers have feasted imaginatively upon the brief eighty-five 
verses of the book of Ruth for many centuries. Recent proposals that Ruth and Naomi maintained a sexual relationship thus fall within the tradition of creative reading to some extent. Stimulated by the contemporary 'sexual subtext hypothesis', the present study performs semantic, syntactical, and intertextual literary analysis upon Ruth 1:14 in order to sketch the outer bounds of creative space that the text itself opens and allows.

Semantic study of דבק reveals that sexual activity is not within the semantic range of the verb. Though in a handful of cases דבק appears in discussion of relationships that include a sexual component, literary context provides the reader information on the sexual activities of subject and oblique complement, not דבק.

The syntax of Ruth 1:14 depicts momentary, significant, contrasting actions; Ruth 'clings' as Orpah concurrently leaves. Thus the plain sense of 'clinging' in Ruth 1:14 does not characterise the enduring Ruth-Naomi relationship, but instead constitutes a single action in the developing narrative.

Lastly, the present study evaluates the probability of intertextual connection between Ruth 1:14 and Genesis 2:24. Richard Hays's seven criteria of intertextual assessment indicate that Genesis 2:24 likely stands in the background of Ruth 1:14. However, a specifically lesbian reading is correspondingly unlikely and runs counter to accumulated semantic, syntactical, and intertextual evidence. Suggestion of a sexualised mother-in-law/daughter-in-law relationship grows less and less credible the closer one approaches the text and its literary details sharpen in focus.

In contrast, Genesis 2:24 offers an interpretive insight into the story of Ruth that is thematically coherent, historically plausible, and in concord with interpretive history, yet which is nearly inconceivable to the sexualised, impoverished Western imagination. In Genesis 2:24, the man's husband-wife union replaces his bond with his parents as his defining relationship. Allusion to this proverb-like conceptualisation of the primacy of marriage in Ruth 1:14 does not imply that Ruth enacts some sort of relationship with Naomi analogous to that between spouses. Instead, echoes of Genesis 2:24 gently beckon the reader to recall Ruth's marriage to Mahlon. Ruth's first husband leaves Naomi to cling to Ruth: an act of solidarity made especially radical due to the union of Jew and non-Jew. Yet Ruth's decision to cling to Naomi carries even weightier consequences. She voluntarily severs ties of 
religion, land, people, and family of origin, but not by creating a new family as if by marriage. Instead she lavishes honour upon her family that already exists: the family she joined when Mahlon joined with her. Ruth's loyalty to Naomi even continues through her second marriage to Boaz.

Such depth in a daughter-in-law's commitment to her mother-in-law might seem a bit far-fetched according to the common conventions and experience of marriage in Western culture and thus may prove difficult to imagine. However, postmodern discomfort with Ruth's steadfast clinging does not legitimise importing an alien, anachronistic, erotic subtext into the Ruth-Naomi relationship. Rather, the book of Ruth unfolds a drama of lifelong devotion between in-laws: a decidedly countercultural challenge to contemporary conceptions of loyalty in marriage. 
